\title{
Penerapan Fuzzy Inference System Untuk Mengendalikan Kecepatan Motor Induksi 3 Phase
}

\author{
Sugeng \\ Prodi Teknik Elektro FT UNPAM \\ Jln. Puspiptek Raya No 11Buaran, Tangerang Selatan 15310 INDONESIA \\ ${ }^{1}$ penulis1@unpam.ac.id
}

\begin{abstract}
ABSTRAK
Penerapan Fuzzy Inference System untuk mengendalikan kecepatan Motor Induksi 3 phase. Salah satu kelemahan motor induksi adalah memiliki beberapa karakteristik parameter yang tidak linier terutama resistansi rotor yang memiliki nilai yang bervariasi untuk kondisi operasi yang berbeda, sehingga tidak dapat mempertahankan kecepatannya secara konstan bila terjadi perubahan beban. Oleh karena itu untuk mendapatkan kecepatan yang konstan terhadap perubahan beban diperlukan suatu kontroler. Tujuan penelitian ini untuk menerapkan sistem pengendali motor induksi 3 phase dengan menggunakan Fuzzy Inference System metode Mamdani melalui simulasi menggunakan Fuzzy Logic Toolbox GUI pada MATLAB. Dengan adanya pengendali tersebut diharapkan kecepatan motor induksi dapat konstan walaupun mendapat perubahan beban. Berdasarkan hasil uji coba sistem pengendali dengan Fuzzy Inference System metode Mamdani menghasilkan kecepatan yang konstan pada saat motor induksi diberi beban mulai dari $0,5 \mathrm{Nm}$ sampai dengan $1,75 \mathrm{Nm}$.
\end{abstract}

Kata kunci :Motor Conveyor, Kontroler, FIS

\section{ABSTRACT}

Application Fuzzy Inference System for Speed Control of Three Phase Induction $\begin{array}{lll}\text { Motor. One disadvantage ofthe induction motoris to } \\ \text { havesomecharacteristicparametersarenotlinear, } & \text { especially therotorresistancehas }\end{array}$ avaluewhich variesfordifferent operating conditions, so itcan not maintaina constantspeedwhenthe loadchanges. Therefore, toobtainaconstantspeedto load changesrequires acontroller. The purposeof this studyto implementa3 phaseinductionmotor controller systemby using themethod ofMamdaniFuzzyInference Systemviasimulationusing theFuzzy LogicToolboxinMATLABGUI. Withthespeedcontrolof induction motorisexpected tobeconstantevengot aload change. Based on theresults of testingthe systemcontrollerswithMamdaniFuzzyInference Systemmethodsproducea constant speedinduction motoratratedloadranging from0.5Nmto $1.75 \mathrm{Nm}$.

Keywords :Conveyor Motor, Controller, FIS

\section{PENDAHULUAN}

$\mathrm{M}$ otor induksi merupakan motor yang paling umum digunakan pada peralatan industri karena perancangannya yang sederhana, murah dan mudah didapat dan dapat langsung disambungkan ke sumber daya AC. Kerja motor induksi berdasarkan prinsip interaksi elektromagnet.
Apabila sumber tegangan tiga phase dipasang pada kumparan medan (stator), akan timbul medan putar dengan kecepatan sinkronsebesar $\mathrm{Ns}=120 \mathrm{f} / \mathrm{p} \mathrm{rpm}$, dimana $f$ adalah frekwensi dalam Hertz dan $\mathrm{p}$ jumlah kutub magnit yang digunakan. Jadi kecepatan putaran motor induksi sangat tergantung pada sumber yang digunakan serta jumlah kutub magnit dari kumparan motor. Dalam penggunaan motor induksi 3 
phase, terdapat beberapa permasalahan antara lain salah satunya pada kondisi tanpa beban, kecepatan motor dapat sesuai yang diinginkan, tetapi setelah diberi beban kecepatan motor akan turun, semakin besar beban yang diberikan maka penurunan kecepatan motor juga akan semakin besar. Hal ini disebabkan karena dengan pemberian beban akan menyebabkan torsi beban bertambah besar sehingga slip bertambah besar yang akan menyebabkan putaran berkurang. Beberapa penelitian pengaturan kecepatan motor induksi telah dilakukan antara lain Ratna Ika Putri (2007), Penerapan Adaptif Fuzzy pada pengaturan kecepatan Motor Induksi 3 phase,Era Purwanto dkk. (2008) Pengembangan Inverter Fuzzy Logic Control untuk pengendalian Motor Induksi.Agus Setiawan dkk, (2010)Neural Fuzzy For Speed Control of Three Phase Induction Motor.Demikian juga penelitian yang dilakukan oleh.Rathod Nirali dan S.K. Shah (2011), Fuzzy Decsion Based Soft Multi Agent Controller for Speed Control of Three Phase Induction MotorPada penelitian ini akan dibangun suatu sistem pengendalian kecepatan motor induksi 3 menggunakan Fuzzy Inference System dengan tujuan mengoptimalkan sistempengendaliankecepatan motor induksi 3 phase sehingga kecepatannyadapat konstan walaupun mendapat perubahan beban dan pada akhirnya menghasilkan performen kerja yang tinggi.Perbedaan utama penelitian yang akan dilakukan dengan penelitian-penelitian tersebut adalah pendekatan sistem kontrolnya menggunakan Fuzzy Inference Systemmetode Mamdani melalui simulasi menggunakan Fuzzy LogicToolbox Graphical User Interface (GUI) pada software MATLAB.

\section{METODOLOGI}

\section{Implementasi Sistem Kendali Motor}

Pengendalian kecepatan Motor Induksi 3 phase diimplementasikan pada sistem dengan diagram blok seperti Gambar 1 dibawah ini:

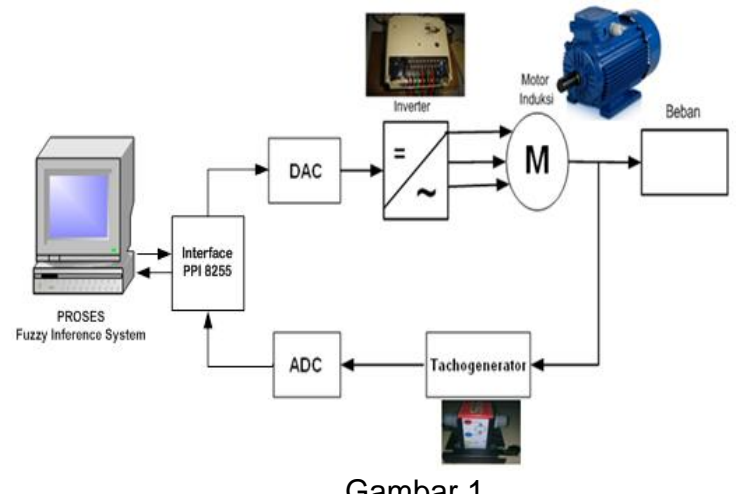

Diagram Blok Sistem kendali kecepatan Motor Induksi

\section{Bahan dan Alat}

Dalam penelitian ini pelaksanaannya hanya merupakan simulasi dari penerapan Fuzzy Inference System metode Mamdani untuk mengendalikan kecepatan Motor Induksi 3 phase dengan menggunakan Fuzzy Logic Toolbox Graphical User Interface (GUI) pada software MATLAB. Oleh karena itu kebutuhan yang sangat mendasar dalam penelitian ini adalah Perancangan sistem kendali dan sebuah Komputer atau Laptop yang berisi software MATLAB.

Sehubungan dengan hal tersebut, dalam penelitian ini menggunakan peralatan sebuah Laptop (hardware) dengan spesifikasi Intel(R) Core (TM) Duo CPU T2450@2.00 GHz, $2 \mathrm{GHz}$ of RAM dan software MATLAB R2011b dengan Operating System Microshoft Windows XP professional Version 2002 Srvice Pack 3.

\section{Tata Kerja}

Untuk merancang pengendali dalam penelitian ini, maka diterapkan Fuzzy Inference System pada sistem pengendalian kecepatan motor induksi 3 phase dengan menggunakan metode Mamdani. Sistem kendali dirancang memiliki 2 buah masukan yaitu masukan yang berupa beban setting (e) dan beban yang terbaca oleh sensor $(\Delta \mathrm{e})$ yang berfungsi sebagai feedback dan memiliki satu output $(\Delta z)$ yaitu perintah kecepatan motor conveyor sesuai gambar 2 dibawah ini: 


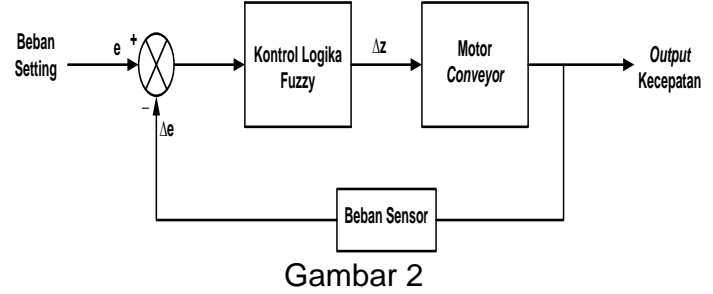

Diagram Blok Sistem Pengendalian Kecepatan Motor Induksi secara otomatis

\section{HASIL DAN PEMBAHASAN}

\section{A. Hasil}

\section{Rancangan Simulasi sistem Kendali kecepatan Motor Induksi dengan Fuzzy Inference System metode Mamdani}

Pembuatan pengujian (simulasi) dengan menggunakan perangkat lunak MATLAB R2011b. MATLAB atau Matrix Laboratory, dipilih sebagai lingkungan percobaan karena kemampuannya mensimulasikan berbagai perhitungan matematis. Dibangun oleh Math Works Inc, MATLAB menyediakan berbagai perangkat pendukung untuk melakukan percobaan pengendalian antara lain Fuzzy Logic Toolbox. Fungsi-fungsi yang terdapat Fuzzy Logic Toolbox dapat digunakan untuk membangun sistem pengendali kecepatan Motor Induksi berbasis Fuzzy Inference System metode Mamdani yang digunakan dalam penelitian ini.

Hal-hal yang menjadi perhatian utama dalam membuat rancangan simulasi dan mengaplikasikan sistem Kendali Logika Fuzzy dalam pengontrolan suatu sistem adalah pembuatan bentuk Membership function pada setiap variabel input dan output serta pembuatan rule base

\section{Pembuatan Variabel Input dan Output pada Software MATLAB R2011b}

Hasil rancangan sistem inferensi fuzzy pada Fuzzy Inference System (FIS) editor pada gambar dibawah ini:

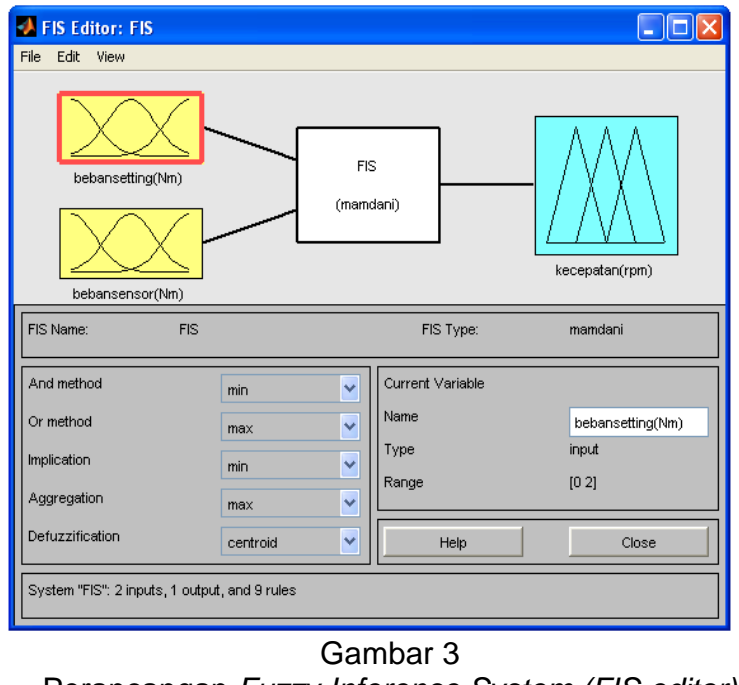

Perancangan Fuzzy Inference System (FIS editor)

Selanjutnya dibuat perancangan fungsi keanggotaan (membership function) pada setiap input dan output pada Membership Function Editor.

Hasil rancangan Membership function untuk Variabel Input 1 (bebansetting) seperti gambar dibawah ini:

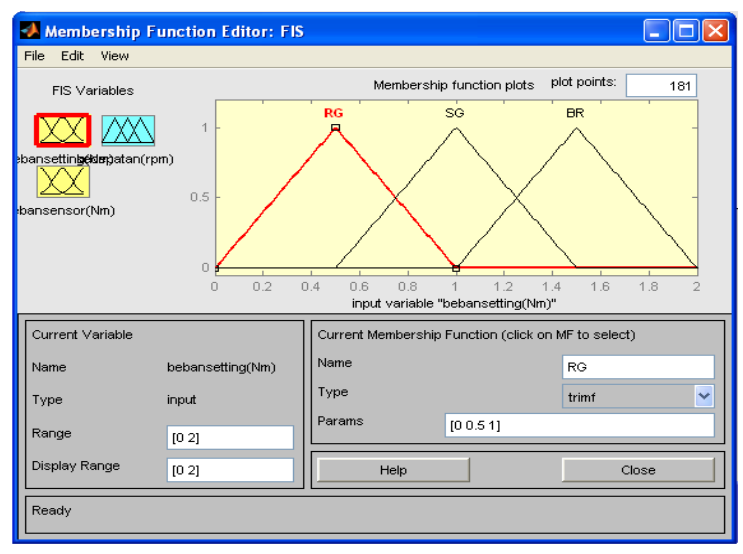

Gambar 4.

Rancangan Membership function untuk Variabel Input 1 (bebansetting)

Hasil rancangan Membership function untuk Variabel Input 2 (bebansensor) seperti gambar dibawah ini: 


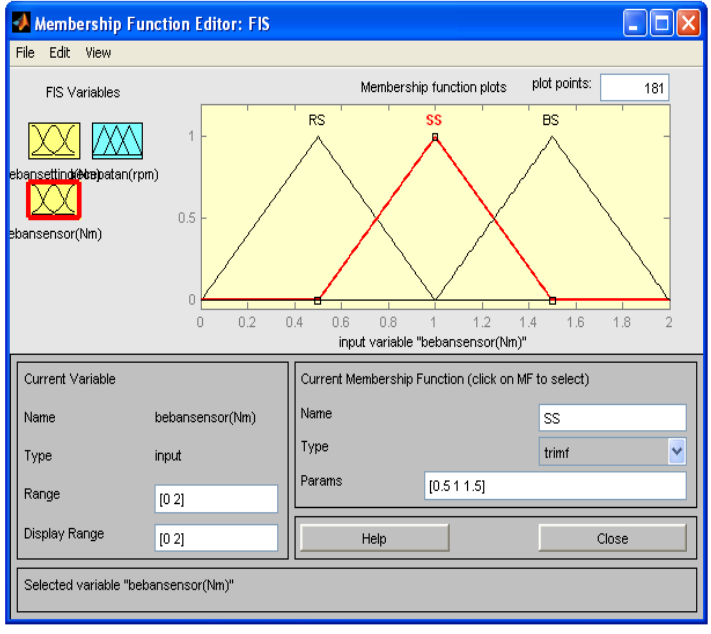

Gambar 5

Rancangan Membership function untuk Variabel Input 2 (bebansensor)

Hasil rancangan Membership function untuk Variabel output (kecepatan) seperti gambar dibawah ini:

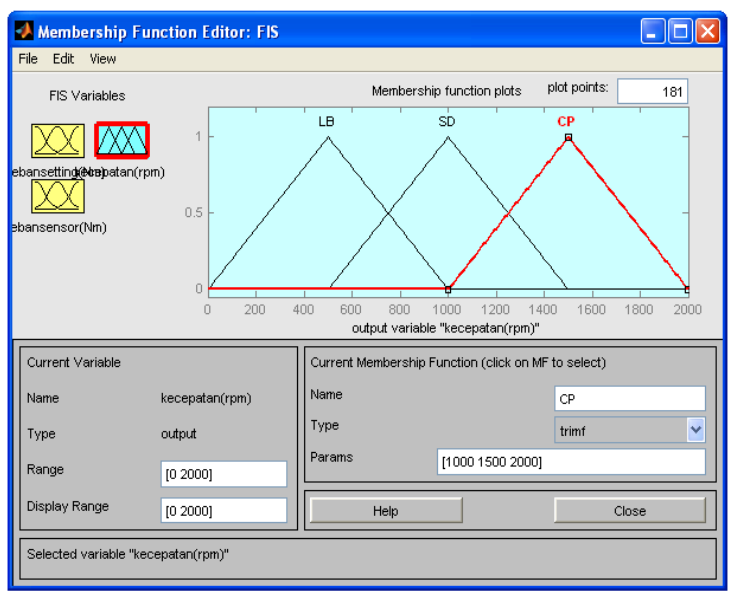

Gambar 6

Rancangan Membership function untuk Variabel output (kecepatan)

\section{Pembuatan Aturan-Aturan (Rule Base) pada Sofware MATLAB}

Hasil rancangan Rule Base pada MATLAB Graphical User Interface (GUI) seperti gambar dibawah ini:

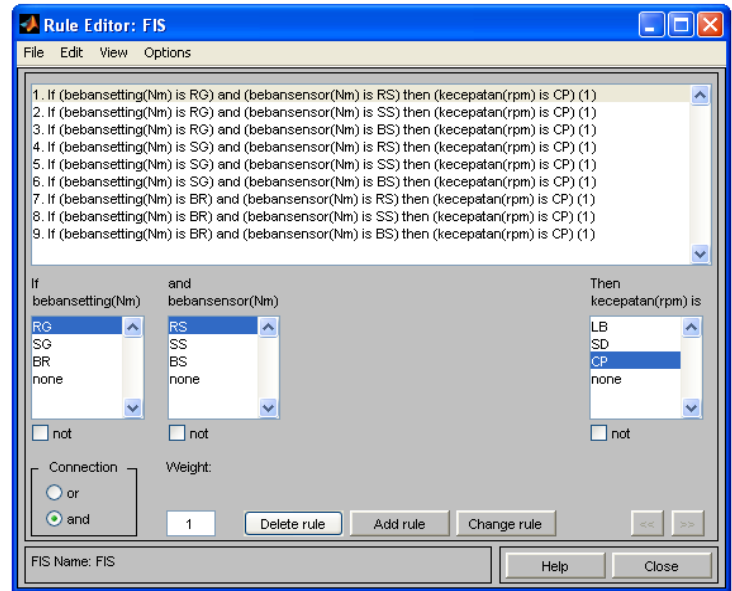

Gambar 7

Perancangan Rule Base

\section{Pengujian Hasil Simulasi}

Setelah dilakukan perancangan parameter-parameter sistem Kendali Logika Fuzzy, kemudian dilanjutkan uji coba untuk menguji hasil perancangan yang telah dibuat.

Uji coba untuk menguji hasil rancangan dilakukan dengan menggunakan Rule Viewer pada MATLAB Graphical User Interface (GUI) sehingga dapat dianalisa hasil output dari sistem apakah sudah sesuai dengan yang diharapkan.

Dalam penelitian ini dilakukan 12 kali uji coba untuk menguji hasil rancangan yaitu:

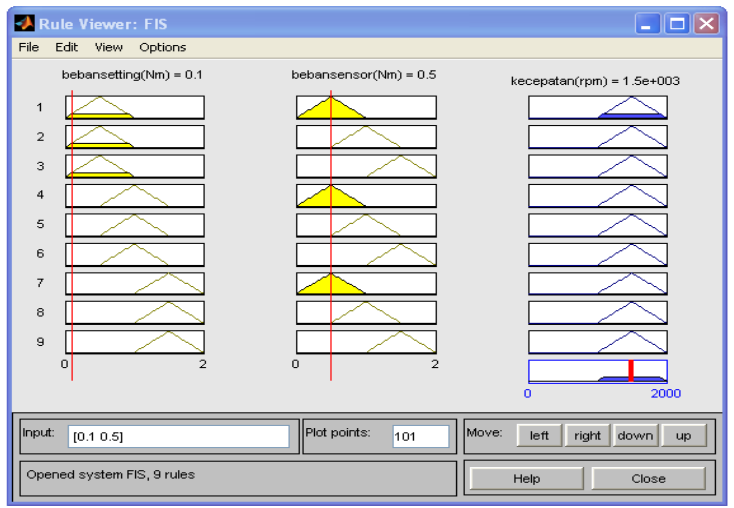

Gambar 8

Hasil uji coba input bebansetting $0,1 \mathrm{Nm}$ dan bebansensor $0,5 \mathrm{Nm}$ 


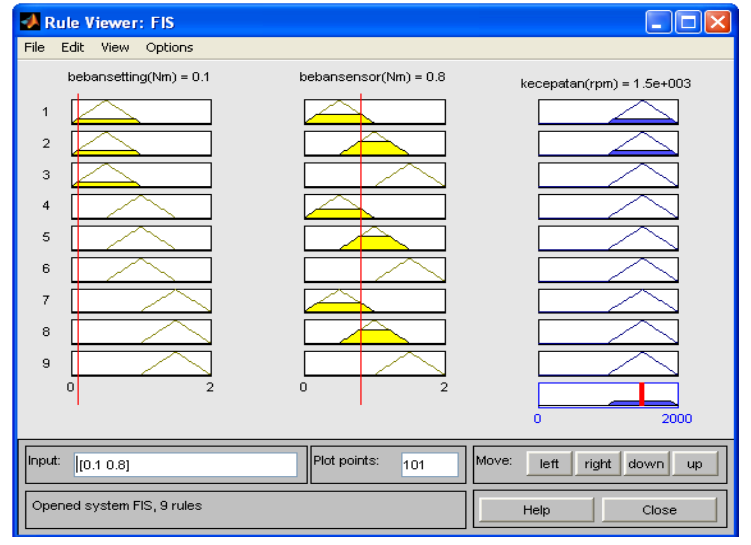

Gambar 9

Hasil uji coba input bebansetting $0,1 \mathrm{Nm}$ dan bebansensor $0,8 \mathrm{Nm}$

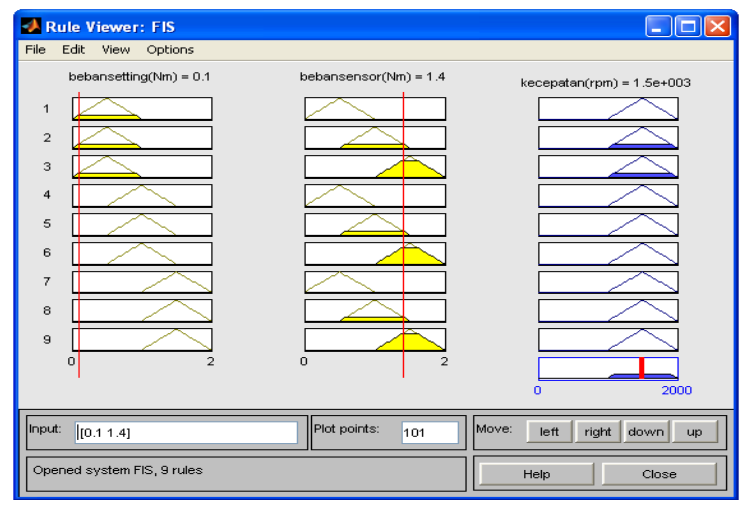

Gambar 10

Hasil uji coba input bebansetting $0,1 \mathrm{Nm}$ dan bebansensor $1,4 \mathrm{Nm}$

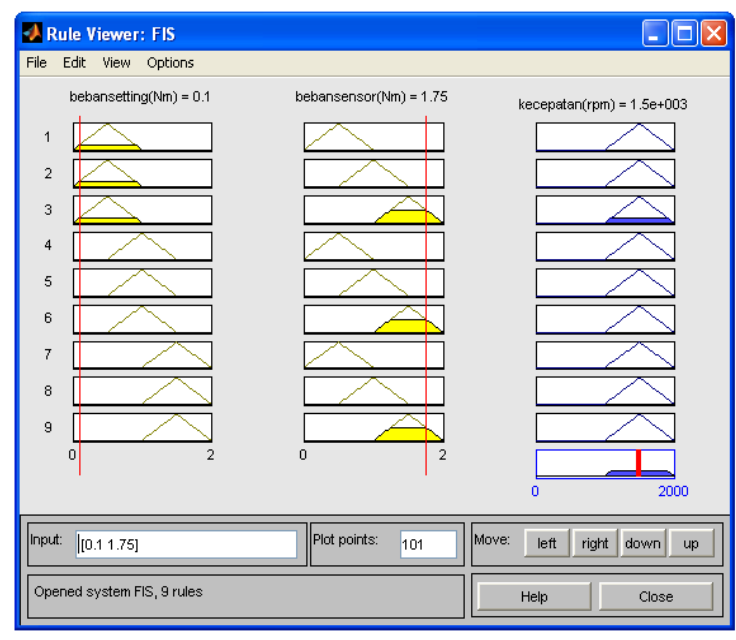

Gambar 11

Hasil uji coba input bebansetting $0,1 \mathrm{Nm}$ dan bebansensor $1,75 \mathrm{Nm}$

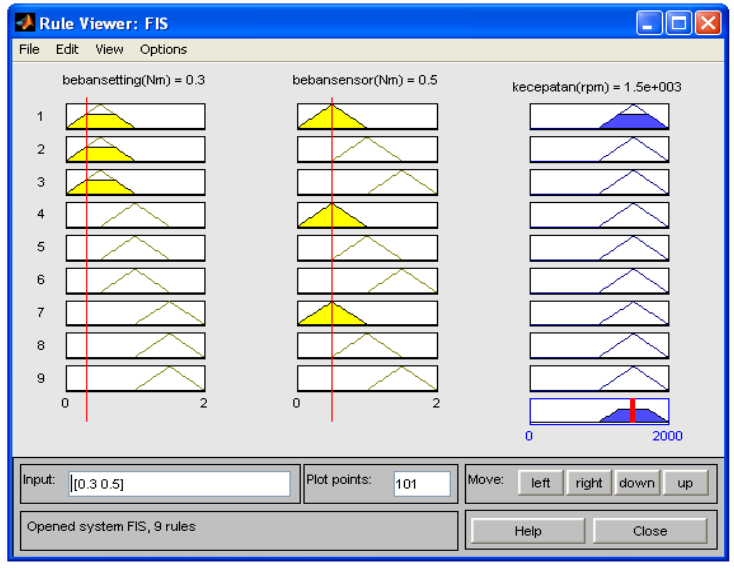

Gambar 12

Hasil uji coba input bebansetting $0,3 \mathrm{Nm}$ dan bebansensor $0,5 \mathrm{Nm}$

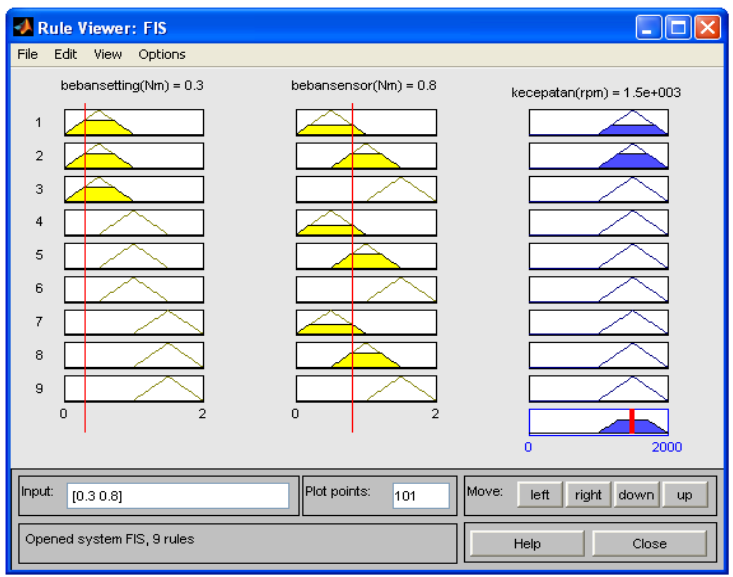

Gambar 13

Hasil uji coba input bebansetting $0,3 \mathrm{Nm}$ dan bebansensor $0,8 \mathrm{Nm}$

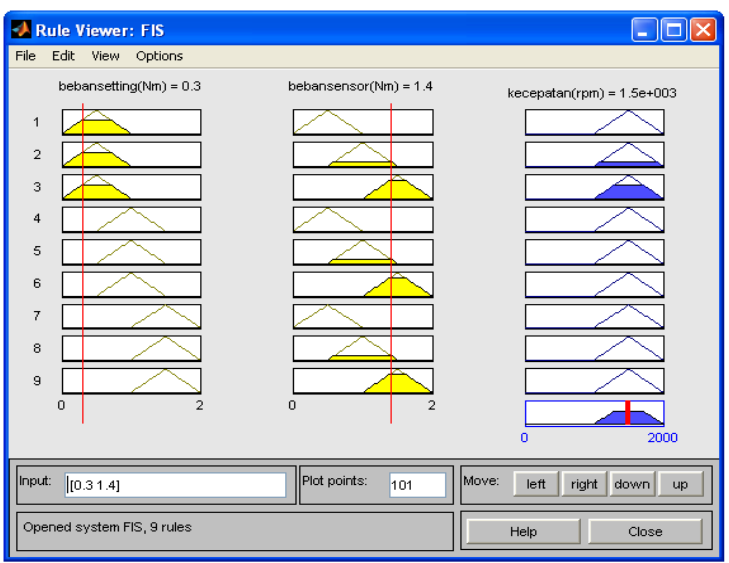

Gambar 14

Hasil uji coba input bebansetting $0,3 \mathrm{Nm}$ dan bebansensor $1,4 \mathrm{Nm}$ 


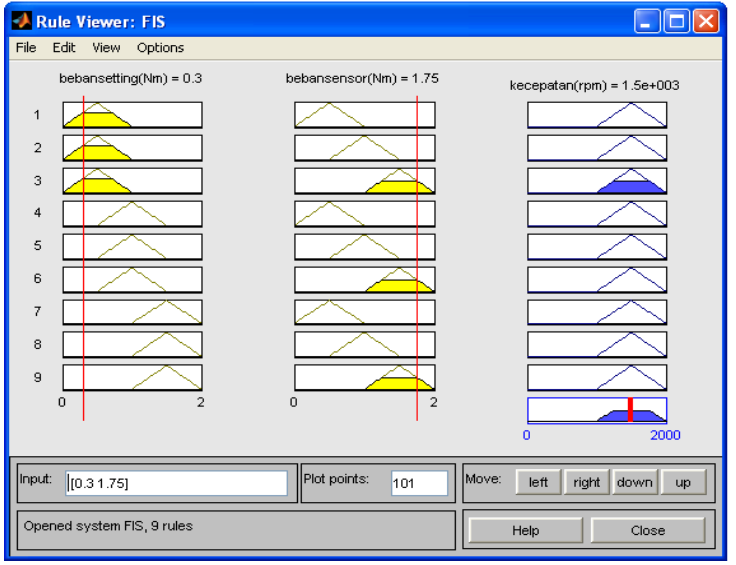

Gambar 15

Hasil uji coba input bebansetting $0,3 \mathrm{Nm}$ dan bebansensor $1,75 \mathrm{Nm}$

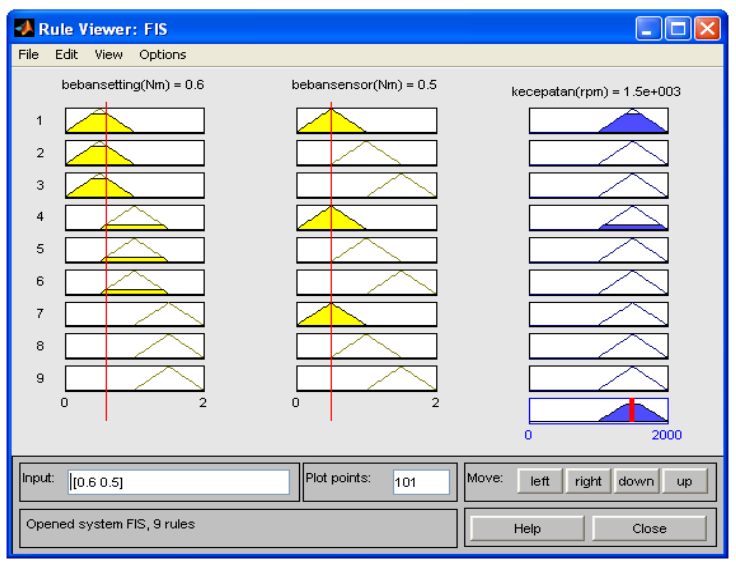

Gambar 16

Hasil uji coba input bebansetting 0,6 Nm dan bebansensor $0,5 \mathrm{Nm}$

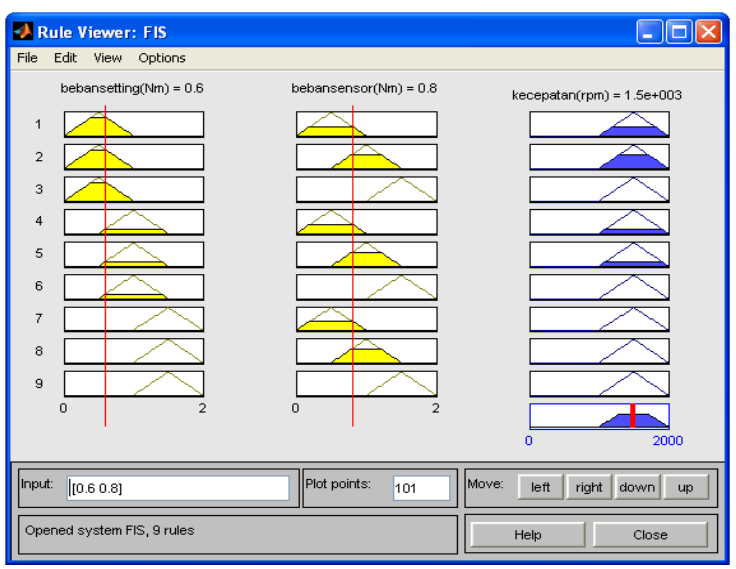

Gambar 17

Hasil uji coba input bebansetting $0,6 \mathrm{Nm}$ dan bebansensor $0,8 \mathrm{Nm}$

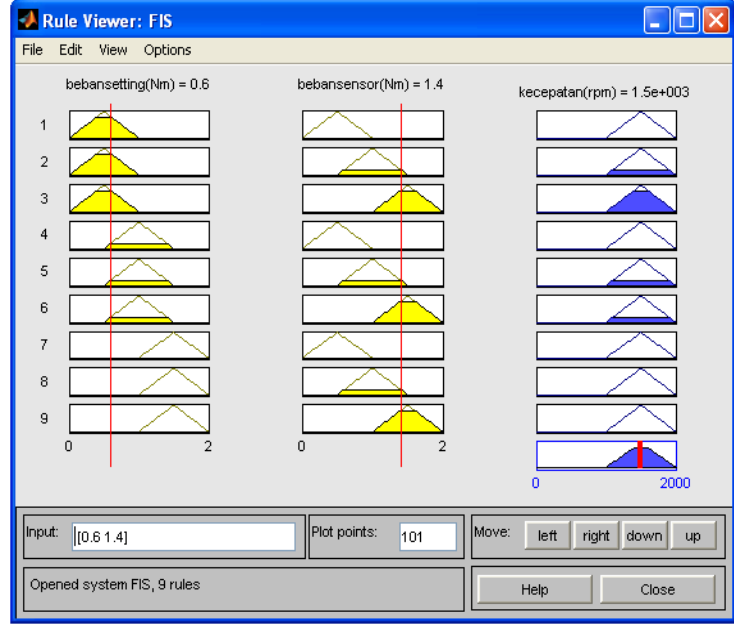

Gambar 18

Hasil uji coba input bebansetting $0,6 \mathrm{Nm}$ dan bebansensor $1,4 \mathrm{Nm}$

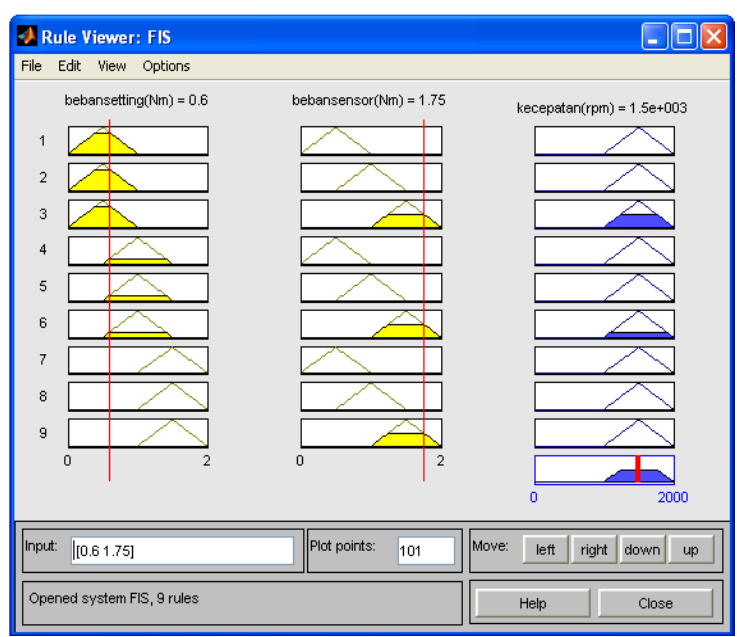

Gambar 19

Hasil uji coba input bebansetting 0,6 Nm dan bebansensor $1,75 \mathrm{Nm}$

Selanjutnya Grafik tiga dimensi yang merupakan hubungan antara input dan output berdasarkan aturan-aturan (rulers) yang dibuat dalam perancangan dapat ditampilkan melalui Surface Viewer pada Fuzzy Logic Toolbox Graphical User Interface (GUI) Tollbox.

Grafik tiga dimensi hasil perancangan sistem dalam penelitian ini seperti gambar dibawah ini: 


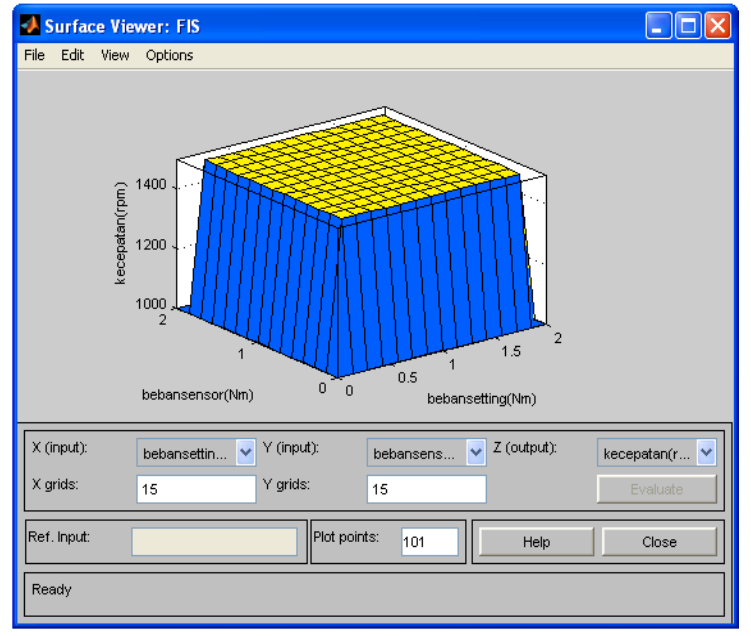

Gambar 20

Grafik Tiga dimensi hasil Perancangan Sistem

Selain menunjukkan grafik tiga dimensi hasil perancangan sistem, Surface Viewer juga dapat menampilkan grafik dua dimensi hubungan antara input 1 (bebansetting) dengan output dan antara input 2 (bebansensor) dengan output hasilnya seperti terlihat pada gambar dibawah ini:

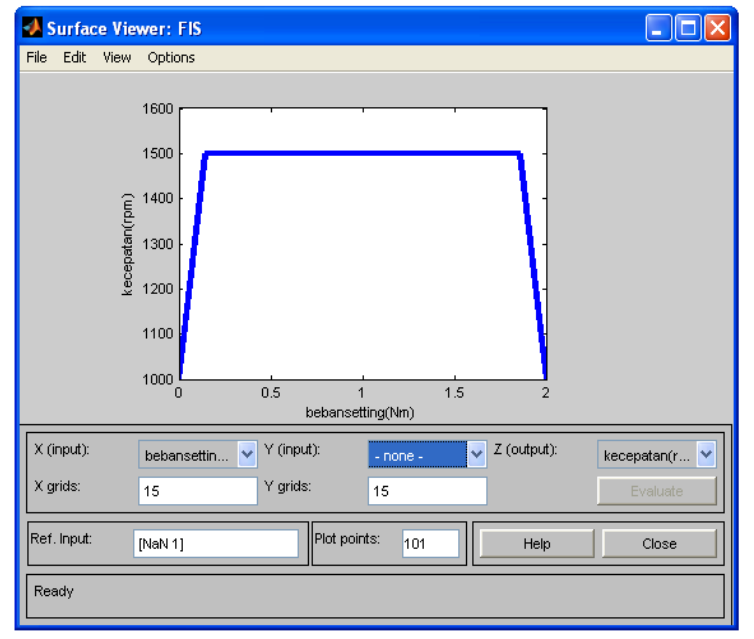

Gambar 21

Grafik Dua Dimensi input 1 (bebansetting) dengan output

Kemudian grafik dua dimensi yang menun- jukkan hubungan antara input 2 (bebansensor) dengan output hasilnya dapat dilihat gambar dibawah ini:

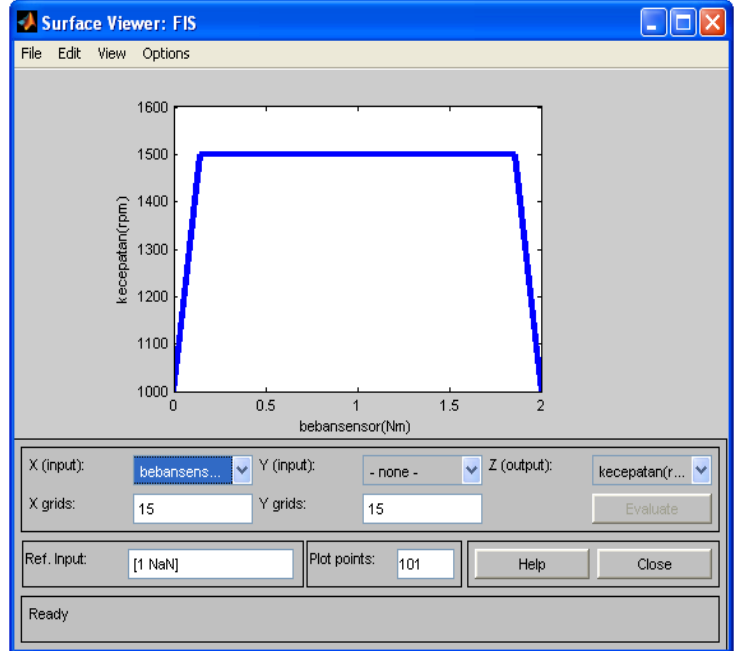

Gambar. 22

Grafik Dua Dimensi input (bebansensor) dengan output

\section{B. Pembahasan}

Dari uji coba yang dilakukan, untuk menguji hasil dalam penelitian ini setelah melalui proses pada MATLAB yang diawali dengan Fuzzification Input beban seting dan Input beban sensor kemudian melakukan inference yang terdiri dari fungsi implikasi dengan metode min dan komposisi antar aturan dengan metode max yang diakhiri dengan proses defuzification metode centroid menghasilkan gambar-gambar Rule Viewer yang menunjukan bahwa pada eksperimen pertama dengan input beban seting sebesar $0,1 \mathrm{Nm}$ dan beban sensor besarnya bervariasi yaitu berturut-turut sebesar $0,5 \mathrm{Nm}, 0,8 \mathrm{Nm}, 1,4 \mathrm{Nm}$ dan 1,75 $\mathrm{Nm}$ memberikan dampak output kecepatan motor tidak berubah yaitu sebesar 1500 rpm. Selanjutnya pada uji coba kedua dengan input beban seting sebesar 0,3 Nm dan beban sensor besarnya bervariasi yaitu berturut-turut sebesar $0,5 \mathrm{Nm}, 0,8 \mathrm{Nm}, 1,4$ $\mathrm{Nm}$ dan 1,75 $\mathrm{Nm}$. memberikan dampak output kecepatan motor tidak berubah yaitu sebesar 1500 rpm. Kemudian pada eksperimen ketiga dengan input beban seting sebesar 0,6 $\mathrm{Nm}$ dan beban sensor besarnya bervariasi yaitu berturut-turut sebesar 0,5 Nm, 0,8 Nm, 1,4 Nm dan 1,75 $\mathrm{Nm}$ memberikan dampak output kecepatan motor tidak berubah yaitu sebesar $1500 \mathrm{rpm}$

Selanjutnya untuk mempermudah melihat langsung hasil uji coba yang dilakukan, 
dalam pembahasan penelitian ini diringkas kedalam tabel-tabel sebagai berikut:

Tabel 1. Uji Coba Pertama

\begin{tabular}{cccc}
\hline $\mathbf{N}$ & $\begin{array}{c}\text { Input1 } \\
\text { (bebanse }\end{array}$ & $\begin{array}{c}\text { Input 2 } \\
\text { (bebansen } \\
\text { sor) }\end{array}$ & $\begin{array}{c}\text { Output } \\
\text { Kecepatan( } \\
\text { rpm) }\end{array}$ \\
\hline $\mathbf{1}$ & $0,1 \mathrm{Nm}$ & $0,5 \mathrm{Nm}$ & $1500 \mathrm{rpm}$ \\
$\mathbf{2}$ & $0,1 \mathrm{Nm}$ & $0,8 \mathrm{Nm}$ & $1500 \mathrm{rpm}$ \\
$\mathbf{3}$ & $0,1 \mathrm{Nm}$ & $1,4 \mathrm{Nm}$ & $1500 \mathrm{rpm}$ \\
$\mathbf{4}$ & $0,1 \mathrm{Nm}$ & $1,75 \mathrm{Nm}$ & $1500 \mathrm{rpm}$ \\
\hline
\end{tabular}

Tabel 2. Uji Coba Kedua

\begin{tabular}{cccc}
\hline No & $\begin{array}{c}\text { Input1 } \\
\text { (bebanset } \\
\text { ting) }\end{array}$ & $\begin{array}{c}\text { Input 2 } \\
\text { (bebanse } \\
\text { nsor) }\end{array}$ & $\begin{array}{c}\text { Output } \\
\text { Kecepatan( } \\
\text { rpm) }\end{array}$ \\
\hline $\mathbf{1}$ & $0,3 \mathrm{Nm}$ & $0,5 \mathrm{Nm}$ & $1500 \mathrm{rpm}$ \\
$\mathbf{2}$ & $0,3 \mathrm{Nm}$ & $0,8 \mathrm{Nm}$ & $1500 \mathrm{rpm}$ \\
$\mathbf{3}$ & $0,3 \mathrm{Nm}$ & $1,4 \mathrm{Nm}$ & $1500 \mathrm{rpm}$ \\
$\mathbf{4}$ & $0,3 \mathrm{Nm}$ & $1,75 \mathrm{Nm}$ & $1500 \mathrm{rpm}$ \\
\hline
\end{tabular}

Tabel 3. Uji Coba Ketiga

\begin{tabular}{cccc}
\hline $\mathbf{N}$ & $\begin{array}{c}\text { Input1 } \\
\text { (bebansett } \\
\text { ing) }\end{array}$ & $\begin{array}{c}\text { Input 2 } \\
\text { (bebansen } \\
\text { sor) }\end{array}$ & $\begin{array}{c}\text { Output } \\
\text { Kecepatan( } \\
\text { rpm) }\end{array}$ \\
\hline $\mathbf{1}$ & $0,6 \mathrm{Nm}$ & $0,5 \mathrm{Nm}$ & $1500 \mathrm{rpm}$ \\
$\mathbf{2}$ & $0,6 \mathrm{Nm}$ & $0,8 \mathrm{Nm}$ & $1500 \mathrm{rpm}$ \\
$\mathbf{3}$ & $0,6 \mathrm{Nm}$ & $1,4 \mathrm{Nm}$ & $1500 \mathrm{rpm}$ \\
$\mathbf{4}$ & $0,6 \mathrm{Nm}$ & $1,75 \mathrm{Nm}$ & $1500 \mathrm{rpm}$ \\
\hline
\end{tabular}

Tingkat optimalisasi beban yang dikontrol bila dibandingkan dengan penelitian sebelumnya dihitung dengan rumus:

Tingkat Optimalisasi $=\frac{(\mathrm{Bhp}-\mathrm{Bps})}{\mathrm{Bps}} \times 100 \%$

Dimana:

Bhp = Beban yang dikontrol hasil penelitian Bps = Beban yang dikontrol penelitian sebelum nya.

Tingkat optimalisasi beban yang dikontrol dalam penelitian ini sebesar:

Tingkat Optimalisasi $=\frac{(1,75 \mathrm{Nm}-1 \mathrm{Nm})}{1 \mathrm{Nm}} \times 100 \%$

$$
=75 \%
$$

Kemudian Grafik tiga dimensi yang ditunjukkan pada Gambar 20 memperlihatkan grafik hubungan seluruh variabel-variabel yang dibuat dalam perancangan sistem yaitu bebansetting, beban dari sensor dan kecepatan motor. Pada grafik tersebut ditunjukkan bahwa kecepatan motor conveyor akan berputar pada kecepatan tetap yaitu $1500 \mathrm{rpm}$ saat bebansetting maupun bebansensor yang berubah-ubah nilainya.

Dari Grafik dua dimensi yang ditunjukkan pada Gambar 21 memperlihatkan grafik hubungan antara input 1 yaitu bebansetting dengan output yang diinginkan. Pada grafik tersebut ditunjukkan bahwa dengan bebansetting yang berubah-ubah kecepatan motortetap sebesar 1500 rpm.

Selanjutnya Grafik dua dimensi yang ditunjukkan pada Gambar 22 memperlihatkan grafik hubungan antara input 2 yaitu bebansensor dengan output yang diinginkan. Pada grafik tersebut ditunjukkan bahwa dengan bebansensor yang berubah-ubah kecepatan motor tetap sebesar $1500 \mathrm{rpm}$.

\section{KESIMPULAN}

Penerapan Fuzzy Inference System metode Mamdani melalui proses yang diawali dengan Fuzzification Input beban seting dan Input beban sensor kemudian melakukan inference yang terdiri dari fungsi implikasi dengan metode min dan komposisi antar aturan dengan metode max yang diakhiri dengan proses defuzification metode centroid dapat membantu mengoptimalkan sistem pengendalian kecepatan motor Induksi 3 phase sehingga kecepatan motordapat konstan walaupun mendapat beban berubah-ubah dari $0,5 \mathrm{Nm}$ sampai dengan 1,75 Nmdengan tingkat optimalisasi beban sebesar $75 \%$ dari penelitian sebelumnya 


\section{DAFTAR PUSTAKA}

\section{BUKU:}

[1] Robandi, I. (2006). Desain Sistem Tenaga Modern Optimasi, Logika Fuzzy dan Algoritma Genetika. Yogyakarta: Andi Ofset

[2] Rose, T. J. (2010). Fuzzy Logic with Engineering Application. John Wiley \& Sons Ltd.

[3] Suyanto. (2008). Soft Computing, Membangun Mesin Ber-IQ Tinggi. Bandung: Informatika.

[4] Kusumadewi, S. (2003). Artifical Intellegence (Teknik dan Aplikasi). Graha.

[5] Parekh. (2003).AC Induction Motors Fundamentals. AN887 Microchip Technology.

[6] Melin, O. C. (2008). Fuzzy Logic : Theory and Application. Berlin: Springer.

[7] Passino, K., \& Yurkovic, S. (1998). Fuzzy Control. Addison Wesley Longmen Inc.

\section{JURNAL:}

[1] Nirali, R., \& Shah, S. (2011). Fazzy Decsion Based Soft Multi Agent Controller for Speed Control of Three Phase Induction Motor. International Journal on Soft Computing (IJSC) Vol.2 No.3 .

[2] Putri, I. R. (2007). Penerapan Adaftif Fuzzy pada pengaturan kecepatan Motor Induksi tiga Fasa. Jurnal Teknik Gelegar Vol. 18 No.1.

[3] Agustiawan. (2010). Neural Fuzzy For Speed Control of Three Phase Induction Motor. International Journal of Computer Science and Network Security (IJCSNS) Vol 10 No. 10 .

[4] Nirali, R., \& Shah, S. (2011). Fazzy Decsion Based Soft Multi Agent Controller for Speed Control of Three Phase Induction Motor. International Journal on Soft Computing (IJSC) Vol.2 No.3

[5] Iswati, L., \& Wahid, F. (2005). Alat bantu Sistem Inferensi Fuzzy Metode Sugeno Orde Satu. SNATI ISBN 979-756-061-6 . 
